\title{
Is ICT a Prospect for Young Professionals to Mature Business Within SME's in East Africa Community?
}

\author{
Murtaza Hussain Shaikh ${ }^{1 *}$, Isabelle Habineza ${ }^{2}$ \\ ${ }^{1,2}$ Department of Business Administration, \\ Kyungsung University, 309 Suyeong-Ro, Nam-Gu, Busan 48434, South Korea \\ *Corresponding author`s email: murtaza [AT] ks.ac.kr
}

\begin{abstract}
Nowadays, young individuals in the East African community are using information and communication technologies in different ways, some as an opportunity to make a conversation with relatives and others take it as a distraction. Information and communication technology is an opportunity for young individuals to grow businesses. Young professionals need to investigate in small and medium-sized enterprises and should not only expect to get jobs elsewhere. The issue is that young professionals in the East African community cannot compete with each other when their mindset on doing business through small and medium-sized enterprises are taken differently and the levels of economic of these countries are very different. This article is motivated by the researcher's observation analysis about young professionals in the East Africa community who know information and communication technologies, and unfortunately, they use them in a way that cannot make small and medium-sized enterprises successful. The main goal of this study is to describe information and communication technologies as an opportunity to buy or sell goods or services through small and medium-sized enterprises. This study will provide a better understanding to the lecturer, especially young professionals to take information and communication technologies positively as an opportunity to grow business through small and medium-sized enterprises and to know the strategy to use to sell products and how to manage consumer's behavior through their needs. Young professionals need to build business skills and linkages with local and international businesses by exchanging business ideas and information via information and communication technologies.
\end{abstract}

Keywords - Integration, SME, Marketing Strategy, Motivation, Professionals

\section{INTRODUCTION}

The regional leaders of EAC have always showered praise on the youth often calling them "leaders of tomorrow", for tomorrow which never comes, and instead of referring them in such positive titles, they should be assisted with education and skills to make them more productive [1]. Youth unemployment rates are generally higher than the national averages except for Uganda as shown in table 1 as youth unemployment ranges from $6.5 \%$ in Uganda to $23 \%$ in Rwanda. In comparison, the unemployment rate for the general public ranges from $7.4 \%$ in Kenya to 17.8 in Rwanda. In addition, unemployment rates for female youth and in the general population exceed that of males in all countries [3]. The ICT in EAC have many constraints included lack of regional ICT master plan, poor coverage of remote and rural areas deficient frameworks for promoting public-private partnerships in sub-sector; and inadequacies of national ICT policies to enable them to meet the challenges of the dynamic technological world [2]. Increased investment in the ICT sector, which is very attractive to young professionals, will not only create a huge potential for jobs, but automation will also improve the operation and delivery of services which again attracts increased investments from the private sector, thus further creating more jobs [4]. Small and medium-sized enterprises (SMEs) are responsible for significant employment and income generation opportunities across the world and have been identified as a major driver of poverty alleviation and development [6]. Small and medium-sized enterprises form the backbone of the African economy, representing more than $90 \%$ of businesses and employing about $60 \%$ of workers, many of whom are women and youth [5]. African SMEs, however, like many in developing countries, are less productive than larger companies and often struggle to survive and grow. Future growth, however, depends on greater SME productivity [10]. SMEs in the ICT sector, however, face a set of daunting challenges including access to business and technical skills, access to regional and global markets and limited early-stage financing. In addition, these organizations must deal with a complex and immature regulatory environment. Despite these challenges, it is evident that SMEs stand to contribute to several new segments of growth for example value-added locally relevant content, as well as software and mobile applications [11]. 
Table 1: Youth of aged 15-24 unemployment rates in terms of percentage

\begin{tabular}{|l|c|c|c|c|}
\hline & Kenya & Rwanda & Tanzania & Uganda \\
\hline Total population & 7.4 & 17.8 & 10.3 & 9.4 \\
\hline Male & 5.3 & 15.2 & 8.2 & 8.0 \\
\hline Female & 9.6 & 21.0 & 12.3 & 11.0 \\
\hline Youth (Age 15-24) & 17.7 & 23.0 & 13.7 & 6.5 \\
\hline Male & 17.1 & 20.4 & 8.9 & 5.5 \\
\hline Female & 20.9 & 26.0 & 14.5 & 7.4 \\
\hline
\end{tabular}

Source: KNBS Kenya Integrated Household Budget Survey, 2015/16; NISR Rwanda Labor Force Survey 2017; NBS Tanzania Integrated Labor Force Survey, 2014; UBOS Uganda National Household Survey, 2012/13 \& UBOS 2016 Labor Market Transition of Young Professionals in Uganda.

Doing business by using ICT, is an opportunity for young professionals to extend business to a large number of professionals from all over the world. Many different elements contribute to business growth. These include providing a good level of customer service, minimizing operational costs and maximizing revenues. Technology can help business to increase productivity and efficiency to reduce costs and maximizing revenues that it can be invested into growing the business [7]. Even though technology can help businesses, then producers must adopt strategies to fulfil consumers' needs. If needed, tactics will be necessary as specific activities to enter in competition with other producers and gain more than before. To do so, producers allow purchasers to be motivated by the products and to extend their products to a large number of professionals. The six members of EAC have some characteristics in common, but also deeply divergent histories, economic endowments and structures, and political systems [9], [10]. The mission of the East Africa community is to widen and deepen economic, political, social and cultural integration to improve the quality of life of the professionals of East Africa through increased competitiveness, value-added production, trade and investments [8]. EAC recognized the importance of ICT in globalization, facilitating regional integration agenda, regional development, deployment of submarine networks to improve international connectivity, developing regional legal frameworks for cyber laws; preparation of a roadmap for the smooth transition from analogue to digital broadcasting and development of a strategy to reform postal sub-sector [12]. The ICT sector has also been confronted with major challenges resulting from the convergence phenomenon. The present situation in the ICT sector is that the strict borders between sectors are disappearing. It is in turn demanding a fundamental rethinking of the traditional sectoral frameworks [15].

\section{LITERATURE REVIEW}

Technology is defined as new machines, equipment, and ways of doing things that are based on modern knowledge about science and computers [13]. The majority of the youth in East Africa face challenges in accessing career, business and education opportunities available, due to limited access to ICT, prohibitive cost and limited and poor infrastructure development especially in the rural areas [10], [14]. ICT is defined as the array of primarily digital technologies designed to collect, organize, store, process and communicate information within and external to an organization and, in our case, SMEs [16]. The integration of ICT into socio-economic parameters in EAC is mainly constrained by inadequate ICT infrastructure and limitations on universal access as well as law ICT knowledge and skills, inadequate legal and institutional frameworks for electronic commerce, e-government and electronic security, low usage of ICT in business and services sectors operations, the negative impact of globalization, poor spectrum management in the face of changing technology and inadequate preparation for the emergence of new technologies [17]. SMEs are defined as businesses that employ 150 professionals or fewer and are not a subsidiary of a public limited company [15]. The mindset of some young professionals is that Small and medium-sized enterprises are destined to be unlettered professionals especially when lettered professionals are oriented to small and medium-sized enterprises. Environmental conditions have an impact on motivation because such as variations in territory potential, the strength of competition can constrain a salesperson's ability, in our case young professionals, to achieve high levels of performance. However, environmental conditions can affect salesperson's perceptions, in our case young professionals, of their likelihood of succeeding and thus their willingness to expend effort [19].

\section{CONSTRAINTS OF ICT ADOPTION FOR YOUNG PROFESSIONALS}

Young professionals starting their businesses have to experience a range of problems. Many of these problems are commonly similar to anyone starting a new enterprise but some problems are related to the youthful age of the entrepreneur. Young professionals have limited business networks and contacts compared with older professionals. They also have fewer financial resources as they have had less time to accumulate personal savings or acquire property. They 
may also experience age discrimination from customers, suppliers or finance lenders [18]. Besides these problems, in many developing countries small and medium enterprises account for a significant share of production and employment and are therefore directly connected to poverty alleviation. Especially in developing countries, SMEs are challenged by the globalization of production and the shift in the importance of the various determinants of competitiveness [12], [15]. Young professionals should especially explore mobile technologies as a large number of professionals have a cell phone and this is a good platform to deliver services [11].

\section{STRATEGY AS A TARGET TO CUSTOMERS}

Young professionals must know that personal characteristics influence selling for building a long-term relationship because professionals in buying are motivated by kind professionals, self-control in emotions, joy, faithful, fairness in the sale, morally ethics, patience, caring for customers, harmonious relationships [7], [9]. Psychological influences on buying; since personal selling requires understanding human behaviour, each salesperson must be concerned with a prospective customer's motivations, perceptions, learning, attitudes and personality. Furthermore, the salesperson should know how each type of behaviour might influence a customer's purchase decision [2]. Understanding buyer behaviour and the communication process, we pass through four stages of the consumer. First is a need state arising when one's desired state of affairs differs from one's actual state of affairs. Second is when a consumer has recognized a need, he or she may not be sure about the best way to satisfy that need. The third is the stage of consumers' decision making a purchase occurs. The consumer has made a decision, and a sale is made and lastly, the goal for markets must not be simply to generate a sale, it must be satisfied and, ultimately, loyal customers [5], [7]

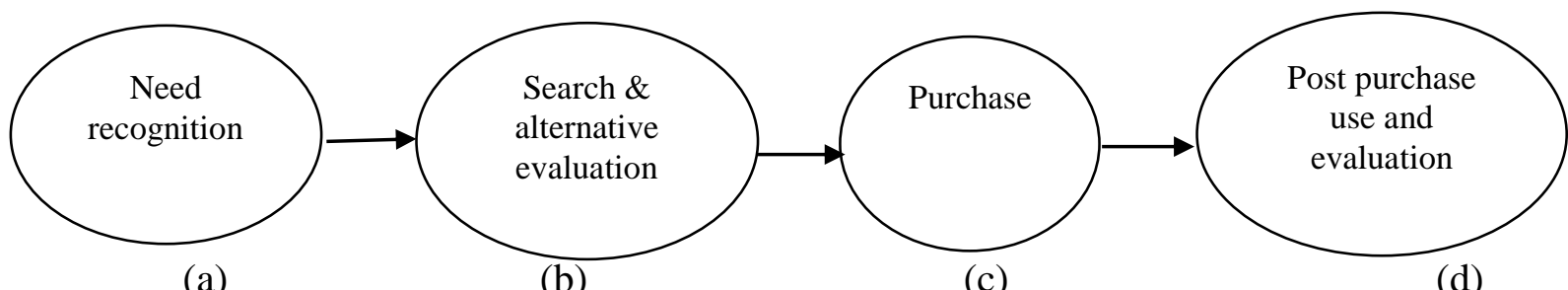

(a)

(b)

(c)

(d)

Figure 1 : Consumer decision making tactile signifiance

Therefore, ICT can enhance young professionals to become operative as well as strategical significance in EAC within SMEs. When they develop a strategic target that causes professionals to desire to buy a product, the needs of customers will build up internally. Young professionals with the required skills in ICT are well placed to generate their jobs by identifying for governments or international agencies a range of other uses for geographical information systems [19].

\section{METHODOLOGY}

The methodology is focused on the problems to be investigated in a research study and hence is varied according to the problems to be investigated [13]. There are common research strategies used in business and management such as experiment, survey, case study, action research, grounded theory, ethnography, archival research, cross-sectional studies, longitudinal studies and participative enquiry [18]. From these different types of strategies, this research adopted to use the case study research strategy as the appropriate strategy for research.

Adopting a case study strategy allowed the use of multiple sources of data collection and analysis, allowing the researcher to address the research objectives and answer the research question satisfactorily [14], [17]. This research strategy is guided by the researcher's observation that is extremely useful in collecting behavioural data as oppose to attitudinal data. This technique allows the marketers to collect data on what professionals do, rather than what they say they will do [8]. This research study will help the researcher to know how young professionals living in EAC use ICT to contribute to the growth of business in SMEs. Doing Business in SMEs in EAC is responsive to the needs of policymakers. Rules and regulations are under the direct control of policymakers. And policymakers intending to change the experience and behaviour of businesses will often start by changing rules and regulations that affect them [9]. Developing and linking into extranets will allow small firms to exploit the business benefits of ICT. This may also allow SMEs to forge strategic alliances with other organizations. Creative use of the internet will also allow SMEs to take advantage of market opportunities [10]. Therefore, the role of youth in the community is trying to develop creative and innovative thinking, for example participating in community organizations and wanting to be involved in the role of government policy-making processes and being able to disseminate specific empowerment for the community. The community itself becomes a forum for young professionals to express creative and innovative ideas [12]. 


\section{RESULTS}

SMEs in EAC don't have rules and regulations that they can guide young professionals to start business and show them how to deal with customers' behaviours and so that young professionals should be creative by using ICT. The ICT itself in EAC have many constraints such as lack of regional ICT master plan, poor spectrum management in the face of changing technology and inadequate preparation for the emergence of new technologies cause also young professionals in EAC are not operative as well strategical significance within SMEs. Young professionals are not assisted to get education and skills to be productive according to the praise of regional leaders of EAC. Also, they are not motivated to get employed see that youth unemployment rates are generally higher than the national averages. Young professionals have limited business networks and contacts compared with older professionals that can make them not get a large market where they can sell their products. Young professionals in EAC undergo many constraints in business networks that make the most of their time using ICT as advertising. In general, most young professionals do not know the strategy to create business networks and how to build long-term relationships with their buyers. It is due to their characteristics and problems of youthful age discrimination in the business area from some customers that take them as unable.

\section{DISCUSSION}

SMEs in EAC need to strengthen rules and regulations to teach young professionals to develop strategy targets that cause professionals to desire to buy a product through on the job training, workshops, upskilling courses and other business development initiatives. The regional Leaders in EAC should interplead how to motivate young professionals by implementing government policies that aim young professionals to be operative in SMEs and they should also do the sensitize campaign about how young professionals can express creative and innovative ideas through ICT by giving them an online interactive and exchange ideas. To deal with young professionals about the use of ICT as an opportunity to buy or sell goods or services through small and medium-sized enterprises, young professionals need educations and skills since they are kids to create a sensitive consciousness of working with modern technologies. The SMEs' ICT should build a culture that is innovative and favourable to technology [3], [4]. Then, Young professionals in EAC need to become aware of and understand the benefits and the importance of ICT within SMEs. The regional Leaders in EAC can adopt an ICT culture within the business that is functional for all countries members of EAC by making business more reliant on technology. Young professionals in EAC need training sessions to understand both the importance of ICT in SMEs and the business aspect. These sessions would be helpful to them to know ICT as a key to SMEs competitive capability and ICT as a strategic level of the business in the modern world.

\section{CONCLUSION}

The findings of this research show that young professionals spend the most time using ICT as an advertisement because SMEs in the East Africa Community don't have rules and regulations that can help young professionals to bring competitive advantages and hence business growth. It seems also that the use of ICT as an opportunity to grow business within SMEs is not developed to give young professionals the benefit occasion to access easily useful information about goods and services related to SMEs. Young professionals unemployed rates show that investment in education and skills on young professionals is not sufficient to get productive young professionals due to the required skills in ICT are not well placed to generate their jobs. This could be partly due to the relative limitations on universal access of ICT in the East Africa Community and the lack of monitoring technologies that SMEs used as a target of their clients and the need of updating products. The limitations of this research may be how young professionals living in EAC use ICT to contribute to the growth of business in SMEs. Also, some aspects could be defined as a limitation as inadequate time and update data at the disposal of the researcher and the unequal implementation of ICT among countries of EAC. The lack of sufficient knowledge about ICT and getting more information from young professionals from EAC and SMEs employed. Modern monitoring technologies is the most that can motivate young professionals to take advantage to generate in SMEs. In the case of exchange goods and services among young professionals in EAC, there are many complementary factors such as developing and linking into extranets within SMEs by using the benefits of ICT, building strategic alliances within SMEs by using the internet as an advantage of market opportunities.

\section{REFERENCES}

[1] Collis, J. \& Hussey, R. (2009). Business Research: A practical guide for undergraduate and postgraduate students, $3^{\text {rd }}$ edition, New York, Palgrave Macmillan.

[2] Curtain, R. (2001). Promoting Youth Employment through Information and Communication Technologies (ICT): Best Practice Examples in Asia and the Pacific, Australian National University, p19. 
[3] EAC Secretariat. 2013. EAC Youth Policy, Arusha, United Republic of Tanzania. Available online at https://www.eac.int/overview-of-eac (Accessed on 14 ${ }^{\text {th }}$ June 2021).

[4] Fjose, Grunfeld and Green (2010). SMEs and Growth in Sub-Saharan Africa: Identifying SME Roles and Obstacles to SME Growth.

[5] Futrell, M.C. (2009). ABC's of Relationship Selling through Services: Tenth Edition, McGraw-Hill, New York, p2284.

[6] Grobe, S.P. (2017). Understanding industrialization and youth employment policy in the East African Community: Regional rhetoric, national drive, European Centre for Development Policy Management, p3.

[7] InfoDev, (2011). Transforming East Africa ICT Sector by Creating a Business Engine for SMEs: SMEs and the East Africa ICT Sector, p1.

[8] Johnston, W.M. and Marchall, W.G. (2013). SalesForce Management: Leadership, Innovation Technology. Eleventh Edition, Taylor \& Francis Group: New York, p 139.

[9] Kariuki N., J. (2011). Convergence of Information and Communication Technology (ICT) sectors in the East African Community (EAC): Challenges for the current legislative and regulatory frameworks and lessons from the European Union experience, p5.

[10] Kroeze, H.J. (2011). The Role of ICT within small and Medium Enterprises in Gauteng. The University of South Africa.

[11] Maquire S., Koh S.C.L., and Magrys A. (2007). The adoption of e-business and knowledge management in SMEs Benchmarking: An International Journal, Vol.14 No. 1.

[12] Martin, L. (2005). Internet Adoption and Use in Small Firms: Internal Processes, Organizational Culture and the Role of the Owner-Manager and Key Staff; New Technology, Work and Employment.

[13] Matambalya, F., Wolf, S. (2001). The role of ICT for the performance of SMEs in East Africa: Empirical evidence from Kenya and Tanzania, University of Bonn, Center for Development Research (ZEF), p3.

[14] Mayor M. \& al (2010). Dictionary of Contemporary English, for advanced learners. New Edition. German: Longman, p 1811.

[15] O’ Guinn, A. (2013). Integrated Marketing Communications: Promo Instructor Edition, South-Western Cengage Learning, p86-92.

[16] Ritchie, B. and Brindley, C. (2005). ICT adoption by SMEs: Implications for Relationships and Management, New Technology, Work and Employment, p30.

[17] Saunders, M., Lewis, P. \& Thornhill, A. (2009). Research methods for business students, $5^{\text {th }}$ edition, Harlow, Pearson Education.

[18] Southern, A. and Tilley, F. (2000). Small Firms and Information and Communication Technologies 9ICT): Toward a Typology of ICTs Usage, New Technology, Work and Employment, p15.

[19] Yin, R. K. (2003). Case study research: Design and methods, $3^{\text {rd }}$ edition, SAGE Publications, London. The United Kingdom. 